\title{
Penerapan Framework Zachman Dalam Perancangan Arsitektur Sistem Manajemen Penyusunan Anggaran Keuangan Daerah (Studi Kasus UPTD Graha Teknologi Sriwijaya)
}

\author{
Antonius Wahyu Sudrajat \\ Program Studi Manajemen Informatika, AMIK MDP, Palembang \\ E-mail: wahyu.sudrajat@mdp.ac.id
}

\begin{abstract}
Abstrak
Kebijakan-kebijakan pemerintah pusat terutama kebijakan dalam keuangan negara haruslah melibatkan pemerintah daerah. Sebab, kinerja dan pengelolaan keuangan daerah saat ini menduduki posisi penting dalam strategi pemberdayaan pemerintah daerah. Penelitian ini bertujuan untuk menghasilkan rancangan arsitektur Sistem Manajemen Penyusunan Anggaran Keuangan Daerah untuk SKPD Graha Teknologi Sriwijaya, menginventarisasi kebutuhan yang diperlukan dalam pengembangan Sistem Manajemen Penyusunan Anggaran Keuangan Daerah, dan memberikan rekomendasi bagi para pengambil keputusan dalam pengembangan Sistem Manajemen Penyusunan Anggaran Keuangan Daerah. Kerangka kerja yang digunakan dalam pembangunan sistem ini adalah Kerangka kerja Zachman, untuk baris pada kerangka kerja Zachman, yaitu: Scope (Contextual), Business Model (Conceptual), dan System Model (Logical). Pada baris Business Model untuk kolom jaringan (network) menjabarkan letak atau lokasi secara geografis dari masing-masing instansi yang terkait dalam Sistem Manajemen Penyusunan Anggaran Keuangan Daerah. Berikut ini letak atau lokasi dari masing-masing instansi yang terkait, yaitu: Unit-unit SKPD, Dinas Pada Pemerintah Daerah dan Pemerintah Daerah.
\end{abstract}

Kata Kunci - Anggaran Keuangan Daerah, kerangka Kerja Zachman, Enterprise Architecture

\begin{abstract}
The policies of the central government, especially in the country's financial policy must involve local governments. Therefore, performance and financial management of the area currently occupied important positions in the local government empowerment strategy. This study aims to produce architectural design Budgetary Management System for Regional Financial Technology SKPDs Graha Sriwijaya, inventory needs required in the development of Management Systems Regional Financial Budgeting, and provide recommendations for decision makers in the development of Management Systems Regional Financial Budgeting. The framework used in the development of this system is the Zachman Framework, to line the Zachman framework, namely: Scope (Contextual), Business Model (Conceptual), and System Model (Logical). On line Business Models for field network (network) to form two groups of servers, ie servers and server services on education. With the network can support good communication in the areas of financial budgeting.
\end{abstract}

Keywords - Regional Financial Budgeting, Zachman Framework, Enterprise Architecture 


\section{PENDAHULUAN}

Tuntutan terhadap pengelolaan keuangan rakyat Indonesia (public money) secara baik merupakan issue utama yang harus dilakukan pemerintah daerah dalam mewujudkan tujuan pemerintah yang bersih (clean goverment), dimana pengelolaan keuangan daerah yang baik adalah kemampuan mengontrol kebijakan keuangan daerah secara ekonomis, efisien, transparan dan akuntable. Pengelolaan Keuangan Daerah dilaksanakan oleh masing-masing Kepala Satuan Perangkat Daerah (SKPD) selaku pejabat pengguna anggaran atau barang daerah [9].

Unit Pelaksana Teknis Daerah (UPTD) Graha Teknologi Sriwijaya Palembang merupakan unit pelaksana yang ada di Dinas Pendidikan Provinsi Sumatera Selatan. Sesuai dengan Tugas Pokok dan Fungsi (Tupoksi) yang dicantumkan dalam peraturan daerah (PERDA) No. 14 Tahun 2006, UPTD Graha Teknologi Sriwijaya harus merancang dan membuat serta mengimplementasikan program kerja-program kerja sesuai dengan ketentuan yang berlaku.

Beberapa kesuliatan yang dialami UPTD Graha Teknologi Sriwijaya adalah keterlambatan dalam membuat laporan pelaksanaan, pembuatan kontrak, pencairan dana kegiatan, program yang tidak dapat dilaksanakan karena beberapa kode rekening sudah dibekukan, kesalahan nomor kode rekening, perubahan nomor kode rekening yang tidak di informasikan sebelum program dibuat dan perubahan nomor rekening setelah DPA disetujui oleh DPRD, penjadwalan sebuah proyek yang akan mulai dilaksanakan sampai penutupan sebuah proyek, dan manajemen dokumentasi proyek yang tidak terorganisir. Masalah yang terjadi pada umumnya terletak pada sistem manajemen penyusunan anggaran yang masih menerapkan caracara yang konvensional, yang dimulai dari penentuan pagu indikatif, penyusunan program dan kegiatan, pemeriksaan RKA SKPD dan dana yang digunakan, sampai dengan diperoleh RKA SKPD yang disetujui[4].

Solusi yang dapat ditawarkan untuk mengatasi hal tersebut adalah dengan membangus Sistem Manajemen Penyusunan Anggaran Keuangan Daerah yang dapat digunakan dalam melakukan penyusunan rencana kerja, pengajuan anggaran atas rencana kerja, penatausahaan atas kegiatan rencana kerja dan pencairan dana, dan sampai pada proses monitoring kegiatan serta pembuatan laporan anggaran keuangan daerah.

Untuk membuat perancangan arsitektur Sistem Manajemen Penyusunan Anggaran Keuangan Daerah dalam skala nasional, tidaklah mudah. Diperlukan framework arsitektur sistem informasi dan teknologi informasi yang memadai. Dalam penelitian ini Kerangka kerja yang digunakan dalam membangun sistem adalah kerangka kerja Zachman, alasannya adalah kerangka kerja Zachman memiliki keunggulan dalam proses perencanaan yang komprehensif dalam keseluruhan enterprise, sekaligus memberikan ciri yang spesifik dari berbagai sudut pandang. Dalam sebuah survey pada tahun 2005, oleh Institute for Enterprise Architecture Developments (IFEAD) menunjukkan bahwa, dari keseluruhan perusahaan yang diteliti, ternyata kerangka kerja yang paling banyak digunakan adalah Zachman yaitu sebesar $25 \%$ [9]. Pada penelitian ini perancangan arsitektur yang akan dibagun hanya terfokus pada kolom data, proses, dan network seperti yang ditunjukkan pada Gambar 1[10].

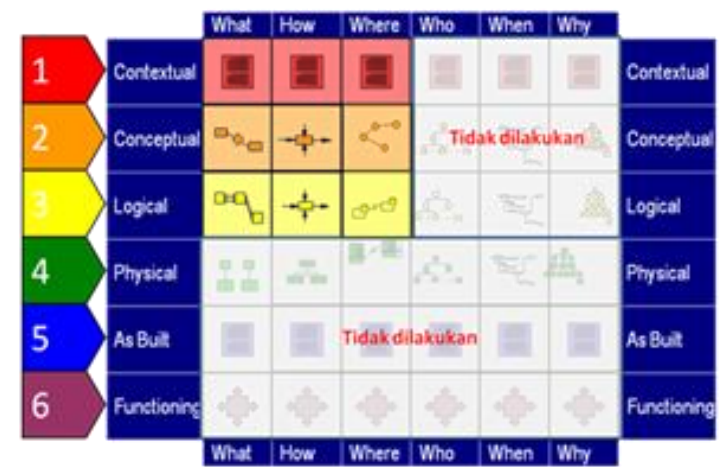

Gambar 1. Ruang Lingkup Cel Pada Zachman Framework 


\section{METODE PENELITIAN}

Dalam melakukan penelitian ini penulis melakukan langkah-langkah yang dilaukan secara sistematis agar apa yang diinginkan dapat tercapai. Gambar 2 merupakan langkah-langkah yang dilakukan oleh penulis dalam melakukan penelitian ini.

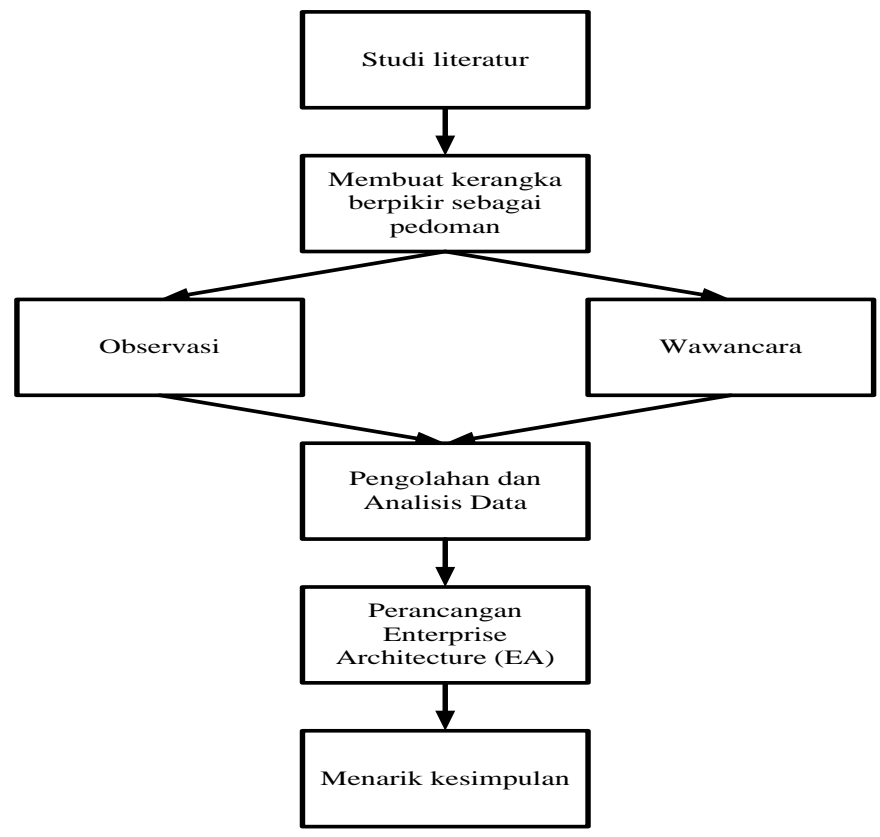

Gambar 2. Tahapan Penelitian

Keterangan:

a. Studi literatur

Pada awal sebelum penelitian dilakukan, penulis melakukan studi literatur yang terkait dengan perancangan Enterprise Architecture khususnya menggunakan kerangka kerja Zachman.

b. Menentukan kerangka berpikir

Tahapan ini dilakukan penyusunan kerangka berpikir dalam penelitian. Penyusunan kerangka berpikir dalam penelitian ini akan disesuaikan dengan kerangka berpikir dari kerangka kerja Zachman. Kerangka kerja Zachman merupakan kerangka yang akan menjadi pedoman dalam perancangan Enterprise Architecture Sistem Manajemen Penyusunan Anggaran Keuangan Daerah.

c. Wawancara

Metode ini digunakan untuk mengumpulkan informasi yang berkaitan dengan data, pelaku, dan proses dalam penyusunan anggaran keuangan daerah.

d. Observasi

Metode observasi digunakan peneliti untuk memperoleh data yang tidak dapat diungkapkan melalui wawancara karena berbagai sebab.

e. Pengolahan dan Analisis data

Data yang telah diperoleh dari hasil wawancara dan observasi diolah sebagai bahan dalam melakukan perancangan Enterprise Architecture. Data yang diperoleh merupakan data mengenai data yang digunakan dalam proses penyusunan anggaran keuangan daerah, lokasi atau instansi yang terkait dalam penyusunan anggaran keuangan daerah, pelaku yang berkepentingan dalam penyusunan anggaran keuangan daerah, waktu yang digunakan dalam penyusunan anggaran keuangan daerah, dan motivasi dalam penyusunan anggaran keuangan daerah. 
f. Perancangan Enterprise Architecture

Data yang telah diperoleh selanjutnya dianalisis agar diperoleh rancangan Enterprise Architecture Sistem Manajemen Penyusunan Anggaran Keuangan Daerah yang disesuaikan dengan kerangka kerja Zachman.

g. Menarik kesimpulan

Tahapan ini merupakan rangkuman dari hasil pengumpulan data dan analisis hasil perancangan Enterprise Architecture Sistem Manajemen Penyusunan Anggaran Keuangan Daerah.

\subsection{Tinjauan Pustaka}

\subsubsection{Pengelolaan Anggaran Keuangan Daerah}

Dalam rangka meningkatkan kinerja anggaran daerah, salah satu aspek penting adalah masalah pengelolaan keuangan daerah dan anggaran daerah. Untuk itu diperlukan pengelolaan keuangan daerah yang mampu mengontrol kebijakan keuangan daerah secara ekonomis, efisien, efektif, transparan dan akuntable. Berdasarkan Permendagri No. 13 Tahun 2006 Pengelolaan Keuangan Daerah adalah keseluruhan kegiatan yang meliputi perencanaan, pelaksanaan, penatausahaan, pelaporan, pertanggungjawaban, dan pengawasan keuangan daerah[7].

Pengelolaan Keuangan Daerah dilaksanakan oleh masing-masing Kepala Satuan Perangkat Daerah (SKPD) selaku pejabat pengguna anggaran atau barang daerah[9]. Adapun tugas pejabat pengelola keuangan daerah adalah sebagai berikut:

a. Menyusun dan melaksanakan kebijakan pengelolaan APBD.

b. Menyusun rencana APBD dan rancangan perubahan APBD.

c. Melaksanakan pemungutan pendapatan daerah yang telah ditetapkan dalam peraturan daerah.

d. Melakukan fungsi bendaharawan daerah.

e. Menyusun laporan keuangan yang merupakan pertanggungjawaban pelaksanaan APBD.

Sedangkan Kepala Satuan Kerja Perangkat Daerah (SKPD) menurut Waluyo, selaku pejabat pengguna anggaran atau barang daerah mempunyai tugas sebagai berikut [9]:

a. Menyusun anggaran SKPD yang dipimpinnya.

b. Menyusun dokumen pelaksanaan anggaran SKPD yang dipimpinnya.

c. Melaksanakan anggaran SKPD yang dipimpinnya.

d. Melaksanakan pemungutan penerimaan bukan pajak.

e. Mengelola utang piutang daerah yang menjadi tanggung jawab SKPD yang dipimpinnya.

f. Mengelola barang milik atau kekayaan daerah yang menjadi tanggung jawab SKPD yang dipimpinnya.

g. Menyusun dan menyampaikan laporan keuangan daerah yang dipimpinnya.

\subsubsection{Enerprise Architecture}

Secara spesifik arsitektur merupakan keseluruhan proses mulai dari pemikiran/ ide/ gagasan, kemudian menjadi karya/ rancangan, dan diwujudkan menjadi hasil karya nyata yang dilakukan secara sadar (bukan berdasarkan naluri) dengan tujuan untuk memenuhi kebutuhan akan ruang guna mewadahi aktivitas/ kegiatannya yang diinginkan serta menemukan eksistensi dirinya.

Berikut ini adalah beberapa definisi atau pemahaman mengenai arsitektur:

1. Arsitektur adalah rancangan dari segala jenis struktur, baik fisik maupun konseptual, baik nyata maupun maya[1].

2. Arsitektur adalah struktur dari komponen dimana masing-masing komponen saling berelasi dan prinsip dan panduan dalam merancang yang selalu berevolusi setiap saat [2]. 
Dari definisi diatas dapat memberikan gambaran bahwa arsitektur merupakan suatu rancangan berupa cetak biru yang akan dijadikan dasar untuk mewujudkan suatu karya nyata. Sedangkan definisi dari enterprise adalah organisasi (atau badan lintas organisasi) yang mendukung lingkup bisnis dan misi yang telah ditetapkan[2].

\subsubsection{Kerangka Kerja Zachman}

Zachman framework, dikeluarkan oleh Zachman Institut for Framework Advancement (ZIFA) sebagai hasil pemikiran dari John Zachman. Framework Zachman bukan sebuah metodologi karena framework ini tidak menyebutkan metoda dan proses spesifik untuk mengumpulkan. Hampir dua dekade yang lalu John Zachman, telah meningkatkan suatu bagan yang universal. Untuk melukiskan dan menggambarkan sistem perusahaan secara kompleks dimasa sekarang dan untuk mengatur berbagai perspektif dari suatu organisasi infrastruktur pengetahuan dan informasi. Kerangka kerja Zachman dapat dilihat pada Gambar 4[3].

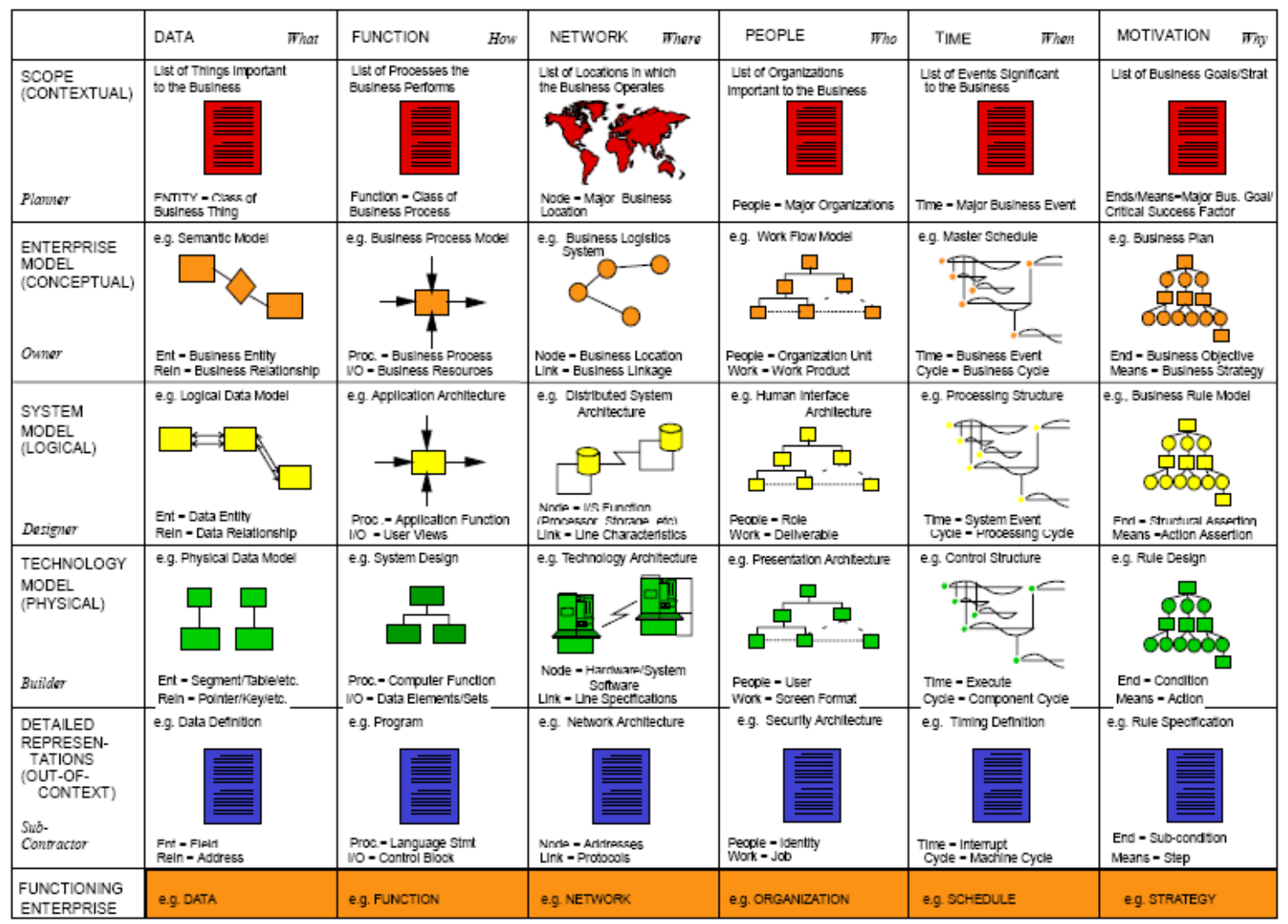

Gambar 4: Zachman Framework

Seperti yang ditunjukkan pada Gambar 4, Zachman Framework mewakili masing-masing perspektif yang ditunjukkan dalam matriks yang terdiri dari 6 kali 6 kotak, dimana 6 baris mewakili perspektif yang berbeda dengan 6 kolom lainnya mewakili aspek organisasi.

John Zachman mendefinisikan kolom dalam matriks untuk menggambarkan data, fungsi, lokasi (dimana bisnis berada), orang-orang yang seharusnya ada dan terlibat dalam organisasi, waktu untuk peristiwa yang terjadi, dan motivasi yang menentukan bagaimana bisnis berjalan. Kemudian, pada bagian baris digambarkan mengenai aspek-aspek development process yaitu: ruang lingkup, model bisnis, model sistem informasi, model teknologi, komponen model, dan sistem fungsi. 
Secara umum perspektif tersebut dibagi menjadi 6 baris[5] yaitu:

1. Scope (ruang lingkup): Biasanya dilihat dari sudut pandang perencana yang mendefinisikan arah enterprise dan tujuan bisnis.

2. Enterprise mode (model Perusahaan): biasanya dilihat dari sudut pandang pemilik perusahaan, mendifinisikan sasaran, strategi, struktur dan proses yang digunakan untuk mendukung sistem atau organisasi.

3. System model: berisi kebutuhan, obyek, aktifitas dan fungsi sistem dalam mengimplementasikan model bisnis. Dalam baris sistem ini kita dapat melihat detil pekerjaan

4. Technologi model: mempertimbangkan batasan faktor manusia, alat, teknologi dan material. Sering disebut dengan baris fisik.

5. Detail representation: mewakili individu, komponen independen yang bisa dialokasikan pada kontraktor untuk implementasi.

6. Functioning enterprise: menggambarkan sistem operasional yang sedang dipertimbangkan sebagai salah satu solusi.

Kolom dalam framework Zachman mewakili enam aspek organisasi adalah sebagai berikut[3]:

1. What (data): menggambarkan kesatuan yang dianggap penting dalam bisnis. Kesatuan tersebut adalah hal-hal yang informasinya perlu dipelihara. Pada kolom data terdiri dari tiga model data yaitu conceptual data, logical data dan physical data model.

2. How (function): mendefinisikan fungsi atau aktifitas. Input dan output juga dipertimbangkan di kolom ini.

3. Where (networks): menunjukkan lokasi geografis dan hubungan antara aktifitas dalam organisasi, meliputi lokasi geografis bisnis yang utama.

4. Who (people) mewakili manusia dalam organisasi dan metrik untuk mengukur kemampuan dan kinerjanya.

5. When (time): mewakili waktu atau even yang menunjukkan kriteria kinerja. Kolom ini berguna untuk mendesain jadwal dan memproses arsitektur.

6. Why (motivation): menjelaskan motivasi dari organisasi dan pekerjaannya. Disini terlihat tujuan, sasaran, rencana bisnis, arsitektur pengetahuan, alasan pikiran dan pengambilan keputusan dalam organisasi.

\subsubsection{Perbandingan Enterprise Architecture}

Dalam pemilihan kerangka kerja, maka yang perlu diperhatikan adalah stakeholder dan domainnya. Pokok utama penggunaan diskripsi enterprise architecture adalah untuk mengkomunikasikan dengan semua stakeholder. Berbagai sudut pandang dari enterprise architecture harus memberikan informasi yang diperlukan stakeholder[6].

Dalam penelitiannya Urbaczewski dan Mrdaij (2006), mengadakan perbandingan beberapa kerangka kerja arsitektur dengan kriteria berdasarkan pandangan stakeholder, abstraksi dan tahapan SDLC. Tabel 1 merupakan Perbandingan kerangka kerja berdasarkan sudut pandang stakeholder [10].

Tabel 1. Perbandingan Kerangka Kerja Berdasarkan Sudut Pandang Stakeholder

\begin{tabular}{|l|l|l|l|l|l|l|}
\hline Framework & Planner & Owner & Designer & Bulder & Subcontractor & User \\
\hline Zachman & Scope & $\begin{array}{l}\text { Business } \\
\text { Model }\end{array}$ & $\begin{array}{l}\text { System } \\
\text { Model }\end{array}$ & $\begin{array}{l}\text { Technology } \\
\text { Model }\end{array}$ & $\begin{array}{l}\text { Detail } \\
\text { Representation }\end{array}$ & $\begin{array}{l}\text { Functioning } \\
\text { System }\end{array}$ \\
\hline FEAF & $\begin{array}{l}\text { Objective/ } \\
\text { Scope }\end{array}$ & $\begin{array}{l}\text { Enerprise } \\
\text { Model }\end{array}$ & $\begin{array}{l}\text { Information } \\
\text { System } \\
\text { Model }\end{array}$ & $\begin{array}{l}\text { Technology } \\
\text { Model }\end{array}$ & $\begin{array}{l}\text { Detail } \\
\text { Representation }\end{array}$ & \\
\hline TOGAF & & $\begin{array}{l}\text { Business } \\
\text { Architecture } \\
\text { View }\end{array}$ & $\begin{array}{l}\text { Technical } \\
\text { Views }\end{array}$ & Architecture & & \\
\hline
\end{tabular}




\section{HASIL DAN PEMBAHASAN}

Perancangan arsitektur sistem yang dilakukan disesuaikan dengan baris yang ada pada kerangka kerja zachman. Baris pada kerangka kerja Zachman menunjukkan sudut pandang dari beberapa aktor yang terkait pada pengembangan sistem, yaitu: penggagas atau perencana (planner Perspective), pemilik (Owner's Perspective), Perancang (Designer's Perspective), pengembang (The Builder's Perspective), dan sub kontraktor (A Sub-Contractor's Perspective).

\subsection{Baris 1 - Scope (Contectual)}

Pada baris ini mendefinisikan tujuan dan konsep Pengembangan Sistem dari sudut pandang penggagas, yaitu: UPTD Graha Teknologi Sriwijaya. Pada baris scope, kolom yang akan diuraikan adalah data, proses, dan network.

\subsubsection{Kolom Data (What)}

Pada baris Scope untuk kolom data diuraikan objek-objek penting yang tekait dalam Sistem Manajemen Penyusunan Anggaran Keuangan Daerah. Objek-objek yang tekait dalam sistem manajemen keuangan daerah adalah RKA SKPD, pagu indikatif, DPA, rekening, urusan, jenis kegiatan, rincian jenis kegiatan, kegiatan, program, dinas, dan unit SKPD.

\subsubsection{Kolom Proses (How)}

Pada baris scope untuk kolom proses (How) akan diuraikan proses apa saja yang dilakukan dalam sistem manajemen penyusunan anggaran keuangan daerah. Proses-proses yang ada dapat dijelaskan berikut ini, yaitu:

a. Penyusunan RKA SKPD

Proses ini dilakukan oleh masing-masing unit SKPD yang ada pada lingkungan Dinas.

b. Penyusunan Program dan kegiatan

Penyusunan program dan kegiatan ini dilakukan oleh subdik perencanaan dan program pada setiap Dinas. Penyusunan program dan kegiatan disesuaikan dengan visi dan misi dari pemerintah daerah.

c. Penyusunan pagu indikatif

Setelah mendapatkan alokasi dana dari pemerintah daerah, masing-masing Dinas akan menyusun pagu indikatif untuk masing-masing unit kerja yang ada dilingkungannya.

d. Pemeriksaan RKA SKPD

Hasil draf RKA SKPD yang telah dibuat, kemudian dilakukan pemeriksaan oleh Biro Perlengkapan, dilihat dari ketepatan dan kesesuaian dengan atauran yang ada.

e. Pemeriksaan Penggunaan Dana RKA SKP

Draf RKA SKPD yang telah disusun oleh unit-unit SKPD kemudian diperiksa oleh Biro Keuangan terkait dengan penggunaan dana pada setiap program dan kegiatan.

f. Pengelolaan Kode-kode Rekenin

Proses ini merupakan proses yang membutuhkan ketelitian, karena masing-masing kegiatan memiliki kode rekening yang berbeda-beda dan jumlah kegiatan yang sangat banyak.

\subsubsection{Kolom Network (Where)}

Pada baris scope untuk kolom jaringan (network) akan diuraikan letak atau lokasi secara geografis dari masing-masing instansi yang terkait dalam Sistem Manajemen Penyusunan Anggaran Keuangan Daerah. Berikut ini letak atau lokasi dari masing-masing instansi yang terkait, yaitu:

a. Unit-unit SKPD

b. Dinas Pada Pemerintah Daerah

c. Pemerintah Daerah 


\subsection{Baris 2 - Business Model (Conceptual)}

Pada baris Business Model menjelaskan sistem dari sudut pandang pemilik (Owner's view), yaitu: Pemerintah Daerah. Pada baris Business Model, kolom yang akan diuraikan adalah data, proses, dan network. Tabel 3 merupakan komponen baris Business Model.

\subsubsection{Kolom Data (What)}

Pada baris Business Model untuk kolom data akan diuraikan rincian informasi dari setiap objek. Gambar 5 di samping merupakan rincian informasi dari masing-masing objek yang ada pada Sistem.

\subsubsection{Kolom Proses (How)}

Pada baris Business Model untuk kolom proses akan diuraikan interaksi aktor terhadap proses dalam Sistem. Gambar 6 menunjukkan hubungan dan interaksi aktor terhadap proses pada sistem yang akan dibangun.

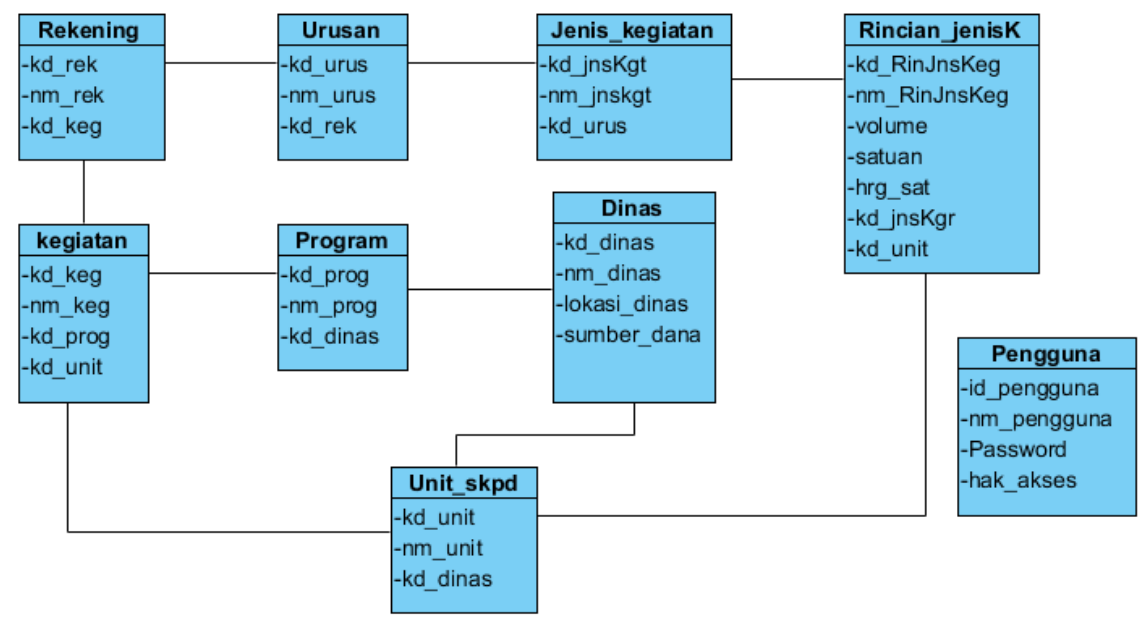

Gambar 5. Rincian Informasi dari Setiap Objek pada Sistem Manajemen

Penyusunan Anggaran Keuangan Daerah

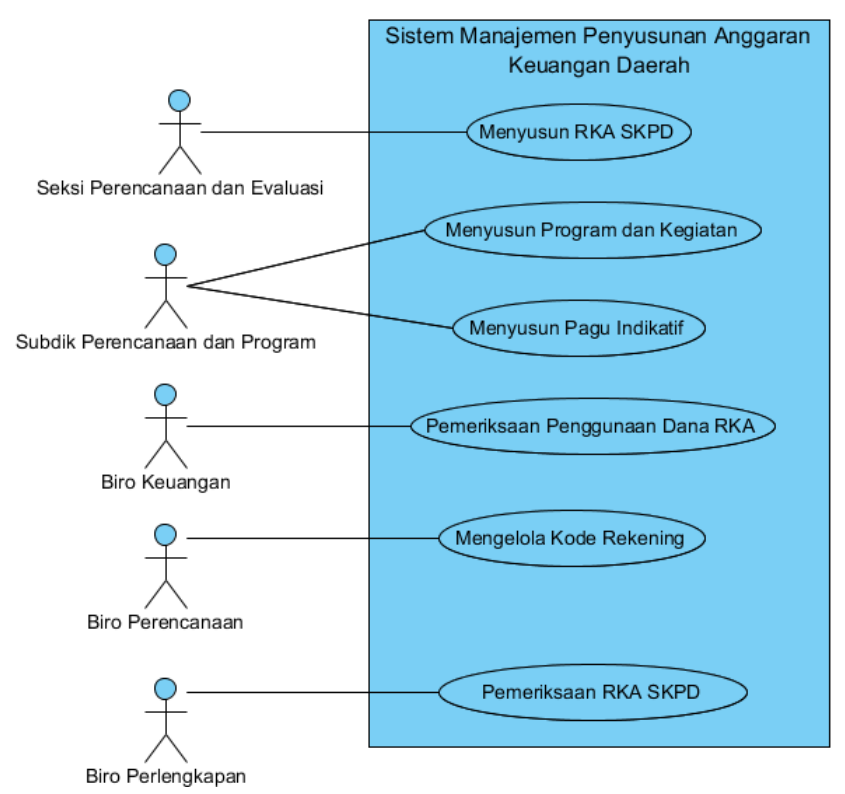

Gambar 6. Diagram Use Case Sistem Manajemen Penyusunan Anggaran Keuangan Daerah 


\subsubsection{Kolom Network (Where)}

Pada baris Business Model untuk kolom jaringan (network) akan dibahas mengenai jaringan pada Sistem Manajemen Penyusunan Anggaran Keuangan Daerah. Gambar 7 merupakan bentuk jaringan dari Sistem Manajemen Penyusunan Anggaran Keuangan Daerah.

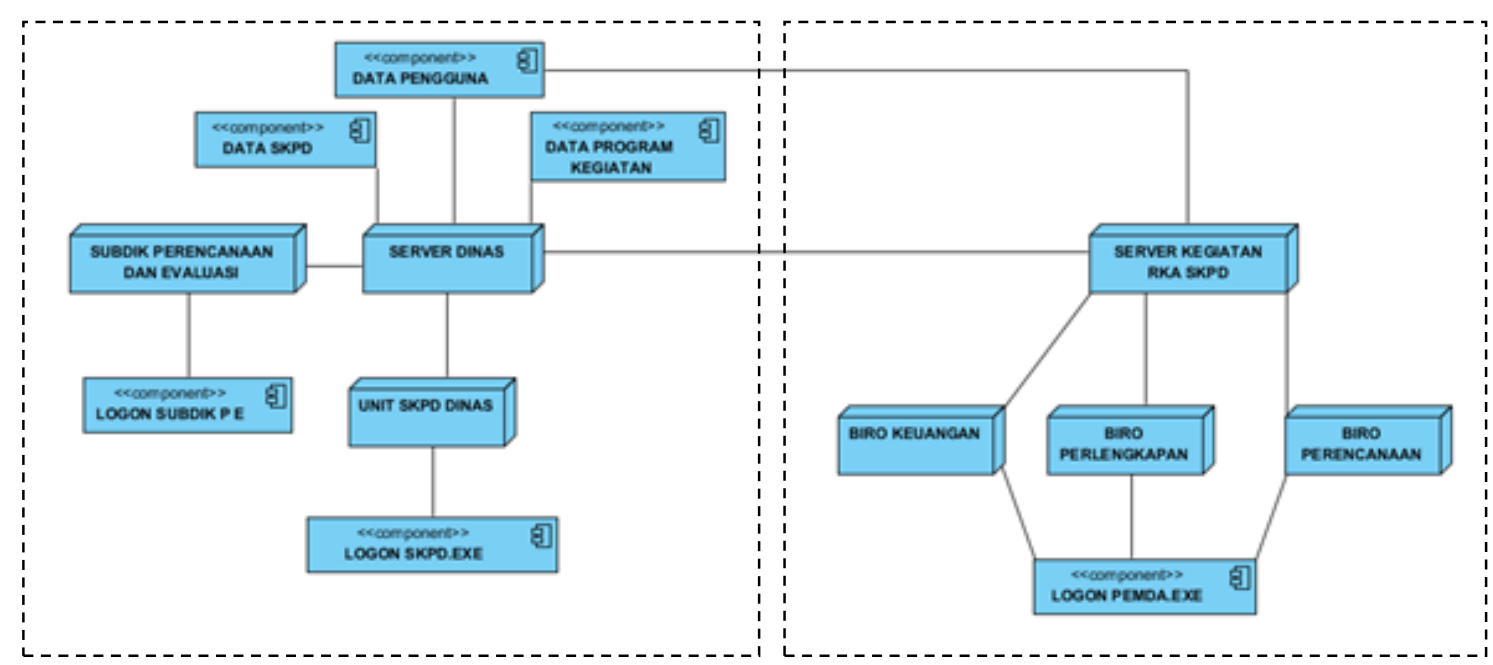

Gambar 7. Konfigurasi Jaringan Dari Sistem Manajemen

Penyusunan Anggaran Keuangan Daerah

\subsection{Baris 3 - System Model (Logical)}

Berdasarkan Scope dan Business Model yang telah didefinisikan sebelumnya, kemudian arsitek (sistem analis) melakukan analisi terhadap proses penyusunan anggaran keuangan daerah, kemudian merancang arsitektur untuk pengembangan Sistem. Pada baris System Model, kolom yang akan diuraikan adalah data, proses, dan network.

\subsubsection{Kolom Data (What)}

Pada baris System Model untuk kolom data akan diuraikan keterhubungan antar objekobjek dalam Sistem. Penggambaran keterhubungan antar objek akan digunakan class diagram yang merepresentasikan bentuk model data dari sistem. Gambar 8 merupakan class diagram pada Sistem.

\subsubsection{Kolom Proses (How)}

Baris System Model untuk kolom proses (How) akan dibahas mengenai interaksi sistem dengan pengguna/aktor pada Sistem. Diagram ini menunjukkan proses aktor ketika berinteraksi dengan sistem, yang dibatasi dengan Tupoksi dan tanggung jawab tiap pengguna/aktor yang berbeda-beda. Gambar 9 merupakan use case diagram dari Sistem Manajemen Penyusunan Anggaran Keuangan Daerah. 


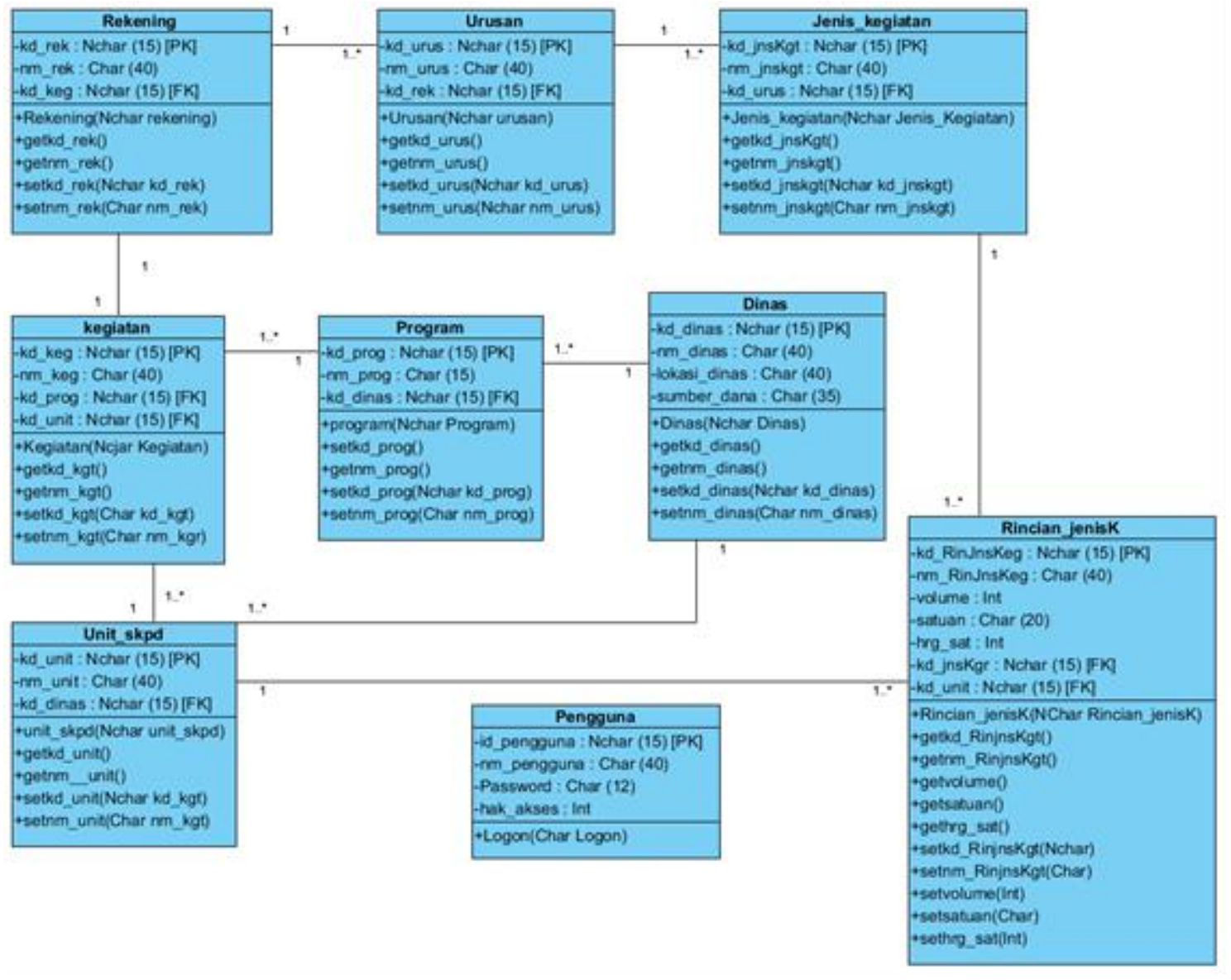

Gambar 8. Class Diagram Sistem Manajemen Penyusunan Anggaran Keuangan Daerah

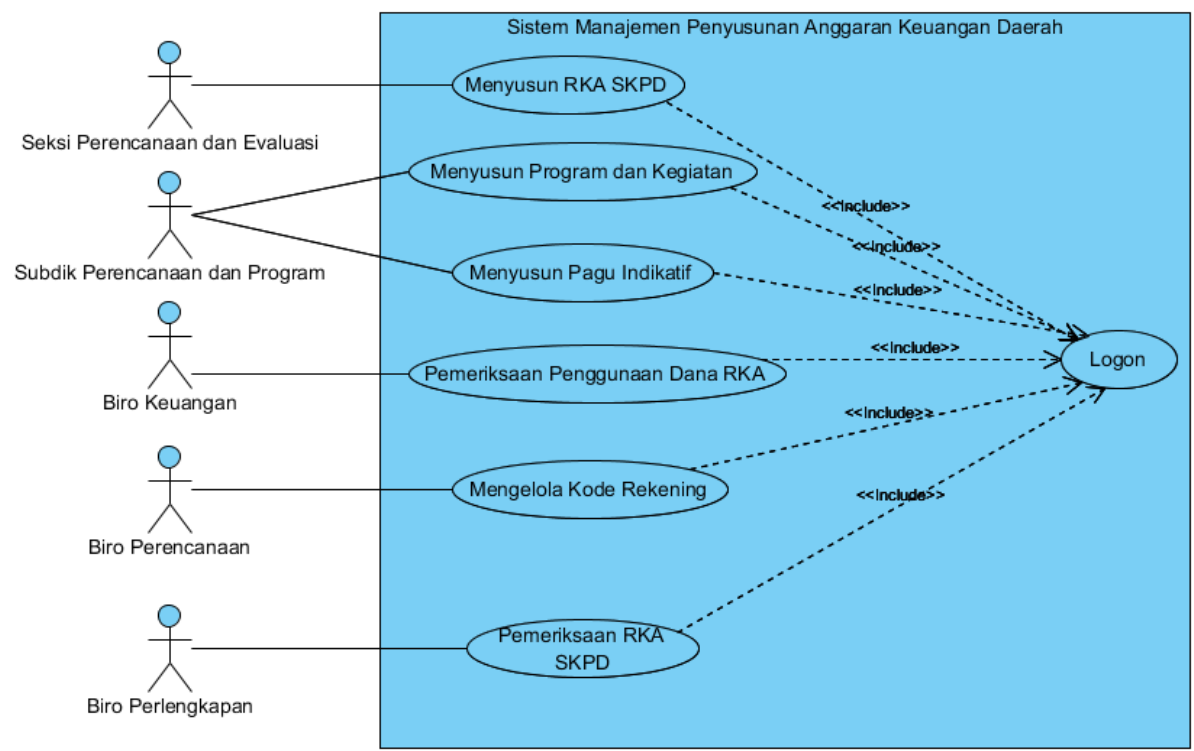

Gambar 9. Diagram Use Case Sistem Manajemen Penyusunan Anggaran Keuangan Daerah 


\subsubsection{Kolom Network (Where)}

Baris System Model untuk kolom jaringan (network) dibahas mengenai jaringan yang digunakan pada Sistem. Untuk menggambarkan jaringan pada Sistem digunakan pemodelan objek dengan component diagram. Gambar 10 merupakan component diagram dari Sistem.

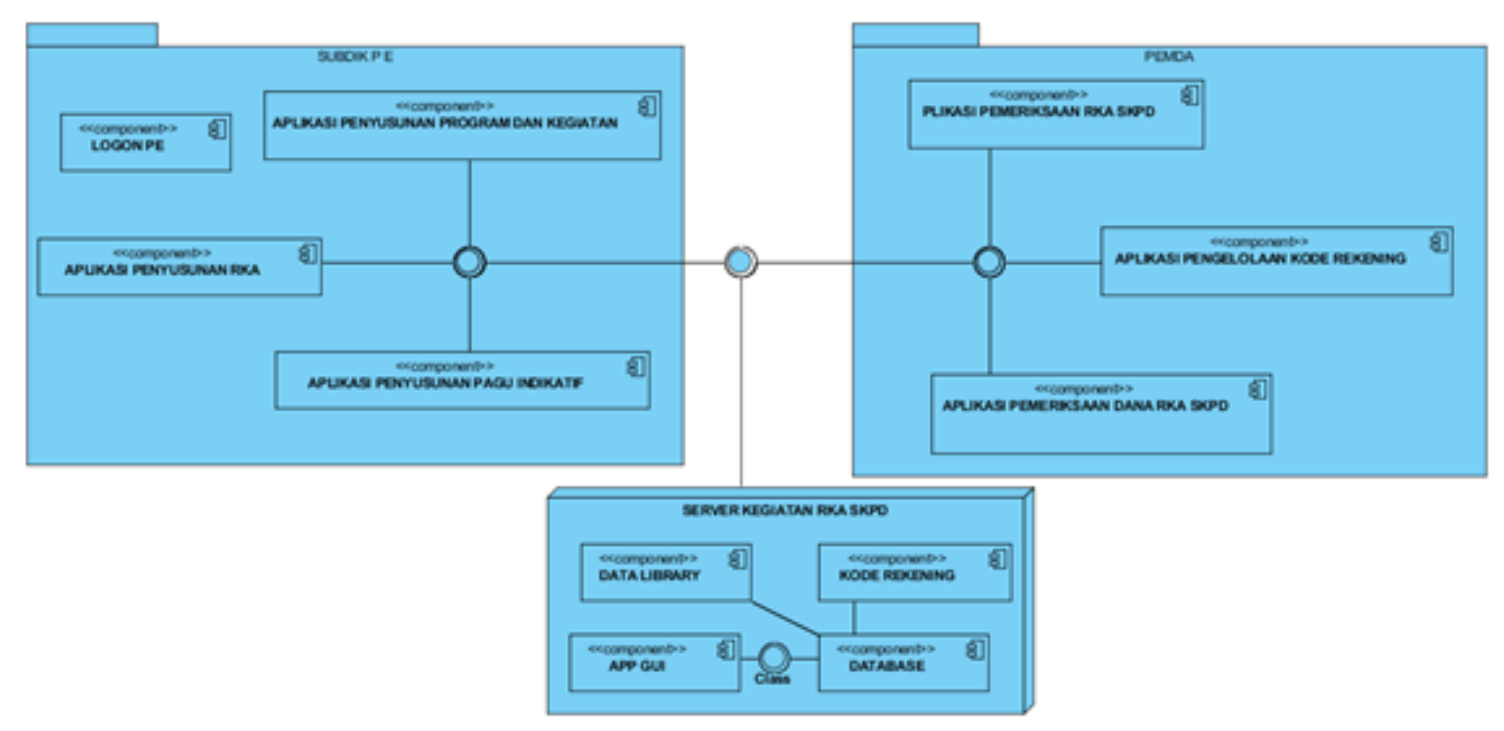

Gambar 10. Component Diagram Pada Sistem Manajemen

Penyusunan Anggaran Keuangan Daerah

\section{KESIMPULAN}

Dari hasil pengumpulan data dan analisis serta interpretasi pada bab sebelumnya, dapat ditarik kesimpulan sebagai berikut:

1. Kerangka kerja Zachman mampu melihat setiap komponen organisasi dari berbagai sudut pandang, yaitu: pertama Scope (Contextual), sudut pandang penggagas, dalam hal ini adalah UPTD Graha Teknologi Sriwijaya. Kedua Business Model (Conceptual), sudut pandang pemilik (Owner's view), yaitu: Pemerintah Daerah. Terakhir adalah System Model (Logical), sudut pandang pengembang, yaitu: arsitek (sistem analis).

2. Dengan kerangka kerja Zachman yang digunakan, tercipta sudut pandang yang holistik dan terintegrasi satu sama lainnya terhadap Arsitektur Sistem Manajemen Penyusunan Anggaran Keuangan Daerah. Hal ini ditunjukkan dengan dihasilkannya sebuah arsitektur data, fungsi, jaringan, sumber daya manusia, waktu dan motivasi yang dapat mengatasi permasalahan yang dihadapi dalam penyusunan anggaran keuangan daerah.

3. Artifac untuk menggambarkan setiap cell pada kerangka kerja Zachman, digunakan Diagram UML, seperti use case diagram, class diagram, sequence diagram, activity diagram, component diagram, dan deployment diagram. 


\section{SARAN}

Di bawah ini akan disampaikan beberapa saran berkaitan dengan penelitian ke depan berkaitan dengan Sistem Manajemen Penyusunan Anggaran Keuangan Daerah. Saran-saran tersebut antara lain adalah:

1. Agar menjadi rancangan yang utuh sesuai dengan kerangka kerja Zachman, untuk melengkapi komponen dan sudut pandang stakeholder dari Sistem Manajemen Penyusunan Anggaran Keuangan Daerah yang belum dikerjakan pada penelitian ini.

2. Untuk dapat mengetahui biaya pengembangan sistem perlu dilakukan penelitian terhadap biaya dan manfaat dari pengembangan Sistem Manajemen Penyusunan Anggaran Keuangan Daerah.

\section{DAFTAR PUSTAKA}

[1] Cook, M., 1996, Building Enterprise Information Architectures: Reengineering Information Systems, Prentice-Hall PTR.

[2] Federal Chief Information Officer Council (FCIOC), 2001, A Practical Guide to Federal Enterprise Architecture, http://www.gao.gov/bestpractices/bpeaguide.pdf, diakses pada tanggal 05 September 2010.

[3] Hay, D. C., 2006, Data Model Patterns: a Metadata Map, Elsevier Inc, San Francisco

[4] Indrawan, 2010, E-Manajemen SKPD APBD UPTD Graha Teknologi Sriwijaya, Prosiding Konferensi Sistem Informasi, Hal 95-103.

[5] Schekkerman, J., 2004, How to Survive in the Jungle of Enterprise rchitecture Frameworks, Trafford, Victoria.

[6] Schekkerman, J, 2005, Trends in Enterprise Architecture 2005: How are organization progressing?, Institute For Enterprise Architecture Developments (IFEAD), Netherland.

[7] UU No. 13 Tahun 2006 Tentang Pedoman Pengelolaan Keuangan Daerah.

[8] Urbaczewski, L., Mrdalj, S., 2006, A Comparison Of Enterprise Architecture Frameworks, Issues in Information Systems (IIS), Vol 7, No 2, Hal 18-23

[9] Waluyo, 2007, Manajemen Publik, CV. Mandar Maju, Bandung.

[10] Zachman, J. A., 2003, The Zachman Framework for Enterprise Architecture: Primer for Enterprise Engineering and Manufacturing, Zachman International. 